\title{
AESTHETICS AND SUSTAINABILITY IN THE RUSSIAN WATER PARKS, FROM THE BAROQUE TO $21^{\text {ST }}$ CENTURY
}

\begin{abstract}
The creation of a representation official park of nationwide scale and importance is hedged about with a lot of difficulties. It is supposed to be a paragon of beauty and utility while also being an epoch's monument remaining in place for long decades or centuries. The paper analyses the balance between the beauty and sustainability in the conception and the actual life of eight parks in the realm of Russian culture (Russian Empire, Soviet Union, Russian Federation). That said, one of them (House of Bezborodko) represents an unconsummated project, but one that is typical of its epoch.
\end{abstract}

Die Anlage eines öffentlichen Erholungsparks von nationaler Reichweite und Bedeutung geht mit zahlreichen Schwierigkeiten einher. Er soll ein Musterbeispiel an Schönheit und Nützlichkeit und zugleich ein epochemachendes Werk sein, das jahrzehnte- oder gar jahrhundertelang erhalten bleiben soll. Dieser Beitrag analysiert die Balance zwischen Schönheit und Nachhaltigkeit in der Konzeption und der praktischen Unterhaltung von acht Parks des russischen Kulturkreises (Russisches Reich, Sowjetunion, Russische Föderation). Einer dieser Parks (von dem Geschlecht der Besborodkos) ist ein nicht-realisiertes Vorhaben, das jedoch typisch für seine Epoche war.

1 A lot of data on the contemporary landscape in those parks exists in the form of museum working papers and has not been published. I owe my colleagues my best thanks for helping me in the work on that topic - Irina Stepanenko (Tsarskoe Selo) who passed away recently, Olga Lameko (Pavlovsk), Svetlana Astahovskaya, Alexandra Alekseyeva and Olga Petrova (Gatchina), Irina Pashinskaya (Peterhof) and Ivan Kossov (Sofiyivka). The inspection of the water system of the Moskva-Volga Canal (from Moscow to the city of Rybinsk) was conducted by the author between 2012 and 2015 for the express purpose of researching on this subject. The work was completed as part of the project 'The history of landscape art in the context of ethnic cultures in Russia, the East and the West: Theory, practical aspects and future development<, grant of the Russian Foundation for Fundamental Research (RFFI) No. 18-012-00826. 


\section{Peterhof from the epoch of Peter I: linear water system}

Peterhof, the first and largest country seat of Peter I, was founded in 1712. By that time, the emperor already had an idea of the parterres' scale in Versailles and the cascades in the Italian Baroque gardens, so he wanted to combine the main features of both systems. In 1705 , books and engravings of Versailles and Marly were acquired, in 1712 a $>$ replica of chamber buildings with a vegetable garden for the Versailles house` (Горбатенко 2015) was bought and kept in the Summer Palace. In 1715, during the second journey through Europe, the emperor met Alexandre Le Blond, responsible for the engravings in Antoine-Joseph Dezallier d'Argenville's work La théorie et la pratique du jardinage and invited him to work for at Sankt-Petersburg. On 23 May 1715, Peter I inspected the cascade at Saint-Cloud, spent the days of 24-26 May in Versailles and was in Marly from 3-12 June. Big albums with plans of Versailles and Marly were sent to Peterhof where they were instantly used to design the parterres, cascades and fountains (Соколов 2019).

Peter knew about the huge issues of the fountains' water supply in Versailles and for this reason gave orders to look for a high place above the shore of the Gulf of Finland to which the water could flow by gravity. The construction of the parterres and the palace in Strelna had already been started slightly earlier, several kilometres from the future Peterhof, however, a source of free-flowing water couldn't be found there. As soon as the engineers made it clear that it was possible to build a canal from the nearby hills to Peterhof and get water in abundance, the emperor shifted his focus exactly to this place, and the residence in Strelna remained unfinished.

Peterhof in the era of Peter I was part of the symbolic topography of the new Russian capital. It is located 30 kilometres from the centre of Saint Petersburg, across from the Kotlin Island where the fortified town of Kronstadt was built at the same time. The Grand Cascade and the Sea Channel were oriented towards it, and the channel was used by the emperor to travel by boat from Petersburg as well as from Kronstadt.

The plan of the water system in Peterhof belongs to the Russian General-Field marshal Burkhard Christoph von Münnich (1683-1767), who proved to Peter the possibility of guiding the water through the channel and pipes from the Ropsha heights, and Alexandre Le Blond and Vasiliy Tuvolkov were responsible for the engineering development. The axis of this water conduct is almost straight along its entire length, which makes the setting even more solemn and impressive. In the 1730s-1740s, the water system of the park was complemented by additional ponds and fountains. The water-supply facilities of Peterhof massively outweigh that of Versailles: with its length of 24 kilometres, it has 22 dams, 18 basins, and the total length of the water conducts is approximately 40 kilometres.

The water system of Peterhof takes its source from numerous springs and further from a creek, the main canal is duplicated by pipes lying in the water, and it doesn't have any tight bends or differences in elevation. Expressing the Baroque aesthetics with its perspective straight line and the copious flux of waters, this system is also a very sustainable and durable landscape object. It provided enough resources and landscape capabilities to cre- 
ate additional scenery in the $19^{\text {th }}$ century, and the destruction from the time of the Second World War could be eliminated quite fast. At the present time, the water system of Peterhof is in a rather trouble-free shape.

\section{Tsarskoye Selo from the epoch of Catherine II: network of landscape channels}

Tsarskoye Selo which is located 20 kilometres south from Saint Petersburg, was created during three epochs. In 1712, Peter I gave the estate to his wife, Catherine I, as a gift. Soon, a small palace was built atop of the hill, and terrace gardens were set up. The water coming in small quantity from streams and bogs formed the Large Pond that was shaped in a hexagonal form. This very unpretentious water system gained traction in the age of Empress Elizabeth when Tsarskoye Selo was developed as a grand Baroque residence. In 1749, a channel that was fed by several springs was dug from the Vittolovo village. Following its course, a chain of ponds was created surrounding the park terraces - three Great cascade ponds on one side and two Small Cascade ponds on the other side.

Under Catherine II, the water system of Tsarskoye Selo experienced sweeping changes. In the middle of the 1760 s, the empress started to turn the formal park into a landscape pleasureground. The chain of cascade ponds and the Large Pond got a natural shape, and the new Alexander Park shaped as a square was surrounded by additional channels. The imagery of Catherine's Tsarskoye Selo is based on the sight of wide water areas and small ducts resembling natural streams. The Cameron Gallery, the Grotto, the Chesme Column and the Admiralty rise above the ponds. This complicated design required new water-supply sources. Water was also needed for the growing towns of Tsarskoye Selo and Sophia. Alongside the Vittolovo channel, another 16 kilometres-long channel was dug from the estate of Taytsy. The resulting water network, part of which is composed of narrow waterways, required high maintenance and depended on the intake of spring water into the channel sources located dozens of kilometres from the park (Степаненко 2017).

The water system of Tsarskoye Selo was restored relatively fast after its destruction in the Second World War. Yet, from the beginning of the 1900s, a degradation of the water conducts set in - a clogging up and destruction of the pipes in the Taytsy channel, and since the 1960s, the area hosting the water sources had been used in an uncontrolled manner. These areas do not belong to the State Museum and Heritage Site of Tsarskoye Selo. Construction works and water withdrawal are carried out there. At the present time, the primary supply source of the water system are melt waters in spring. The water run is low, the dugouts and ducts stagnate. The beauty of this water world turned out to be rather fragile. 


\section{Pavlovsk from the epoch of Paul and Maria: park at the river, ponds with water from Tsarskoye Selo}

Pavlovsk was founded in 1777 as the residence of Paul, son of Catherine II, and his wife Maria. The estate adjoins her residence from the south, and initially, the water collected from the Tsarskoye Selo water system was used to fill the long rivers-like ponds in Pavlovsk. Several parks created out of former forest land were set up in Pavlovsk - The Large Star, Krasnodolinny (Red Valley) park, Old and New Sylvia and Silver Birch. They are grouped on both sides of the winding Slavyanka River that is pent up at several locations. The Slavyanka valley shaped by the Scottish architect Charles Cameron represents an open `English park $\iota$, and the peripheral parks are dense and preserve the soil moisture well. The ponds in Pavlovsk have an ornamental nature and are not combined into a complicated structure like in Tsarskoye Selo (Ламеко 2017).

Maria Feodorovna, born Princess of Württemberg, grew up in the Alsatian city of Montbéliard (in German: Mömpelgard) and kept her love for the country estate in Étupes. It could not be preserved but from the drawing that is stored in Pavlovsk it is apparent that the park had transitional features from the formal to the landscape style, with a few winding roads and several pondlets (Ламеко 2017). Even though some historians assume that Maria wanted to make Pavlovsk a ssecond Étupes`, the nature of the Russian park is radically different. It has a widespread plan, a lot of forest land, and an open, free-flowing river. These properties of Pavlovsk ensured afterwards the independence of its water system from the flow of water from Tsarskoye Selo, and at the present time, despite a deterioration in the condition of the Slavyanka riverhead, the park is in a rather unscathed condition.

\section{Gatchina: wetlands turned into a threefold water system}

Gatchina was founded in 1766 as the property of Count Grigory Orlov, a favourite of Catherine II. It is a compelling landscape design in which the architect Antonio Rinaldi took part. Back then, the swamps were drained and recovered, and the water filled a series of lakes - the peripheral Black Lake and two central ones (the vast White Lake and Silver Lake next to the palace), and then left the park via the duct system. The work on the park extension continued after 1777 when Catherine II presented the estate to her son Paul.

On higher grounds, only artificial non-flowing ponds contained water, and next to the lakes where there was plenty of water, islands and a water maze were set up. One of those islands hosts the Temple of Venus, a replica of the one in Chantilly that Paul and Maria visited in 1782. The Carp Pond next to the palace also repeats the forms of the channel in Chantilly. Each of the lakes has its own matching landscape. Priory Palace was built on the shore of the gloomy Black Lake. It was proposed to be used for the Order of Malta meetings. The narrow Silver Lake serves as a water-table for the palace. The expansive White Lake assembles around itself panoramas, pavilions and was embellished with numerous 
ornately shaped bridges. At the bottom of the water system in Gatchina, Paul and Maria set up the Sylvia Park that copied the regular shape of the garden with the same name in Chantilly. On the shore of the local ducts, pavilions and a bath were set up (Астаховская 2017).

Throughout the $19^{\text {th }}$ century, the complex water system of the park gradually declined. An enormous damage was inflicted on it by the occupation and the systematic destruction during the Second World War. Pieces of blown bridges can be seen at the bottom of the White Lake up to date. The Gatchina Palace and park were destroyed to such an extent that, at first, it was not planned to restore it, and restoration work could only begin in the 1960s. Now, the palace has been fully restored but the park is dogged by huge problems. Degradation and war-time destruction led to waterfloods of the lower ponds and a bogging up of some parts in Sylvia. The balance between irrigation and drainage had been struck by approximately 80 culverts out of which only 7 could be detected at the present time. The White Lake and the Carp Pond are stagnating. Only in 2018, the museum administration had the opportunity to order an inspection of the hydrologic system in Gatchina. Created as an accurately calculated system of large lakes and minor ducts, the water system in Gatchina turned out to be unsustainable to the lack of maintenance in the 19th century and had been half-way destroyed during the war. As also other problems are bound up with the state of the water system in Gatchina (the destruction of the embankment atop the Silver Lake), its restoration is a pressing problem admitting no delay.

\section{The project of Bezborodko Dacha by the architect Nikolay Lvov: the dream of an ancient water park}

Along with existing water parks, we shall consider the unfulfilled plan of a specific estate from the cusp of the $18^{\text {th }}$ and $19^{\text {th }}$ centuries with features of a model project. Nikolay Lvov (1753-1803) was a self-taught architect who appreciated the shapes of the graceful French neoclassicism. He was the first to translate work by Andrea Palladio into Russian language and created numerous projects of city and countryside palaces and churches. However, in landscape architecture, Lvov preferred fantasy and snatural shapes and especially loved to set up distinctive water systems. In 1797, a friend and benefactor of the architect, the Chancellor of Russia Alexander Bezborodko asked him to make a draft for a big country estate modestly called >dachar. The place above the Yauza River looking out over Moscow induced Lvov to get creative, and the circumstances of the order (both Lvov and Bezborodko were seriously ill) mobilized him to create a manor utopia.

Lvov fashions a plan with broad and large shapes in which water and its architectural appearance play a key role. The upper portion of the park above which the palace should be located represents a >natural system of ponds, ducts and cascades. Lvov crafts a vivid image of this sight: having put in motion all this part of the mountain by flowing water, [I] defined it with a living house base (Иванова 2017). In an explanatory text for the album, the author intends to >reconcile the teachings of two opposed artists, namely Kent and Le 
Nôtre (Иванова 2017). The bottom of the water system is a big basin for water amusements and sports with a regular shape which Lvov called Naumachia (likely, under the impression of the Naumachia in Parc Monceau in Paris). A connecting element between the upper and the lower park is a grotto with a statue in front of which a fire burns on a credence, and from above, it is covered by a fan of water jets. This is how Lvov put into action his favorite idea of the fight and union of the elements (Иванова 2017).

The architect stresses in his text that the underpart of the park is of public nature - this is where people exercise and stroll along the basin, where there are cafes on the street and a public water-intake fountain. The big and plain shapes of Naumachia, the calm rhythm of the stairs and colonnades create an ancient, contemplative mood. Despite the utopian nature of Lvov's project, it is a feasible plan, and its well calculated water system could become durable. The historical record of landscape art is not peppered with many examples of water systems in the Empire style. Lvov's project demonstrates a lot of scope for such Classical water aesthetics.

\section{Sofiyivka: a romantic system of rocks and streams}

Sofiyivka, the estate of Stanisław and Sofia Potocki near the town of Uman in Ukraine, owes its existence to a geologic phenomenon. Smooth-faced plains spread all around but, in this place, the river has cut deep gullies and revealed huge boulders. The park that is named after Sofia Potocki was founded in 1797, the main contractor was Ludwik Metzel, a military engineer. The landscape and program of the park is fully based on a combination of stones and water flows. Several grottoes feature waterfalls, there is a spring in one of them. The water was collected in two lakes - the Upper Lake (Sweet Sea) and the Lower Lake (Ionian Sea). Between them, an intermediate lakelet has been set up. The subterranean winding river Acheron runs from the Sweet Sea to this lakelet. Unlike in other park streams with Greek afterlife names (Styx in the English Stowe Park), a huge impact on the visitors coming by boat is made here by the under-earth silence and darkness. The water coming from the in-between lakelet flows into the Great Waterfall, where closed scenes give way to open ones.

All lakes feature quays and crude stone terraces, alongside of the waterfall, the Giants' Valley (big boulders) can be seen, and the feeling of a romantic play between the elements is the main sensation for the visitors. Dramatic scenes intersperse with elegiac ones: on the lateral duct, the low cascade Three Tears dedicated to the memory of three non-surviving children of the Potockis has been set up (Косенко et al. 1996).

After the Polish Uprising in 1831, the park was transferred to the Empress of Russia Alexandra Feodorovna, later, a school of agriculture opened here. But the fame of Sofiyivka, a 'wonder of Ukrainer, kept it intact, and in the $20^{\text {th }}$ century, a museum was set here. Thanks to the vast numbers of visitors, up to 100 tourist coaches per day, this park, though far away from large cities - the distance to Kiev is about 200 kilometres - is in prime condition. The extraordinarily robust `natural water system created by Metzel contributes to this largely. 


\section{Peterhof of Nicholas I: the prolongation of the water axis and new cultural landscape}

The Emperor Nicholas I under the rule of which the Empire style gave way to eclecticism attempted to implement cultural reforms with an effect on the whole society, from nobility to peasants. One of those reforms, an experiment on extensive cultural landscaping, was started by him in Peterhof in the 1820s-1840s. The emperor had close family ties to Prussia and accordingly kept a close eye on the `Kulturlandschaft ‘ of the Potsdam parks. The court architect, Andrei Stackenschneider, was sent to Potsdam to learn from its experience.

In the $1820 \mathrm{~s}$, it was decided to use the channel delivering water to the fountains in Peterhof to set up a system of big ponds. On the Colonial Pond (the name derives from a settlement of German farmers), two garden isles that reminded the Empress Alexandra Feodorovna of Italian villas have been set up. Tsaritsyn Island was dedicated to her, and Olga's Island to her daughter. Further on, up the channel, dams and lateral ponds with a natural shape on which a mill, pavilions, an open-air stage and follies were located have been created. This landscape was populated - military camps and model villages were to be seen around.

The walk through the new landscape continued along the Samson Channel trending off to the right and to the left. The termination of the route was a double view of the buildings signifying the presence of the owners of Peterhof. On a hill above the channel, there is the Belvedere Palace dedicated to the emperor and his court festivities. This peripter was built in antique shapes. The Church of Queen Alexandra, the patroness of the empress, created in the form of old Russian architecture rises nearby. From these buildings located on higher grounds one can see the centre of Saint Petersburg (Пащинская 2017).

The water system in Peterhof of Nicholas I broadens und uses the water conduct built in the era of Peter I without spending any additional water. For this reason, the general water system became even more reliable - now there were reserve ponds to feed the fountains. Despite the destruction of pavilions and shores, the water system in Peterhof survived all troubles of the $20^{\text {th }}$ century and is now in good shape. Over the last years, the pond and the channel have been cleared, and Belvedere and the church have been restored. A growing number of visitors comes to this part of Peterhof that was deserted until recently.

\section{The Moskva-Volga Canal: a new water axis developed since 1937 to this day}

Since the construction of Peterhof in the era of Nicholas I and until the Soviet period, almost no more substantial water parks were created in Russia. In 1935, upon an initiative of Stalin, the general reconstruction plan of Moscow intended to give to the ancient city features of a global capital was adopted. This plan was executed to a very large extent. It included the creation of big radial avenues, squares, monumental street and embankment 
buildings. The colossal Palace of the Soviets with Lenin's statue at the top was a focus of attention, however, its construction was interrupted by the Second World War and never resumed. An enormous difference in the new look of Moscow was and still is made by the renewed water system (Генеральный план реконструкции Москвы 1935).

By the beginning of the $20^{\text {th }}$ century, the Moskva River became low and dirty to a critical extent. There were almost no embankments intended for walks in the city. The Moskva River flows into the medium-sized Oka River next to the city of Kolomna, and the Oka River in turn confluences with the Volga River near Nizhny Novgorod. The general plan involved a connection of the Moskva and Volga Rivers with a canal running through the city and then going 100 kilometres north until it met the Volga River in the town of Dubna. The Moskva-Volga Canal was constructed within a very short time using the labour force of prisoners. The result was an abundant flux of the Moskva River, the creation of water reservoir chains above the city of Moscow and the opening of new possibilities for boats to have access to the Baltic Sea, Caspian Sea and the Black Sea.

The new water system was intended to create a new look for Moscow - a city of broad open river spaces and heavy architecture resembling that of Saint Petersburg. Great buildings with arcs reflected in the river were under design. The accomplished parts of this plan are the North River Terminal and the buildings on the Frounzenskaya embankment. One of the core public functions of the new Moskva River was recreation and sports. By the water reservoir in Khimki, a stadium was constructed, Gorky Central Park of Culture and Leisure not far away from the Kremlin opened, and small recreational crafts were used. The general plan of 1935 even provided for a ring canal around Moscow, however, it was not practical and never constructed. The embankments and monumental bridges became the architectural landmark of the city and as such are featured in dozens of films among which are `The New Moscow` by Aleksandr Medvedkin (1937) and `The Cranes Are Flying ‘ by Mikhail Kalatozov (1957).

The new water system of Moscow had powerful resources that were used later. In the 1950s in Luzhniki, in the bend of the river, the central stadium of the country was built, a view of it opened in the axis of the high-rise block of the Moscow State University. In the 1970s in Krylatskoye District, a water stadium was created. The infrastructure development of the river continued in the post-Soviet period. In 2014-2018, a reconstruction of the embankments was carried out, they were freed from cars, continuous cycling strips with a length of dozens of kilometres were created. In 2017, Zaryadye Park was built on the site of a former Soviet hotel. It is a government project demonstrating the priorities of the administration in relationship with the active part of the population. Zaryadye park provides look out to the Kremlin as well as to the river and its banks. For this purpose, a $>$ floating bridge combining postmodern aspirations to recode the stoo stiff city< and the wish to create the belvedere in the tradition of old-world gardens was built.

The review of the largest water parks in Russia allows for several conclusions. First, complex Baroque systems with an abundance of fountains are not necessarily the most vulnerable ones. The slim and slow ducts in Tsarskoye Selo and Gatchina were damaged by 
time way more badly. When in a situation where constant service of the water structure is difficult to achieve, simple systems like in Peterhof, Sofiyivka and on the Moskva River are in the best shape. Second, a system created at one period is usually more sustainable than a revised one. In Tsarskoye Selo, problems were added by two construction periods, and in Peterhof, the engineers only complemented the existing water axis. Finally, the value of all mentioned landscapes is defined to a great extent by the wellbeing of their water systems. Consequently, the issues of research, reconstruction and the protection of water-carrying areas are thrown into sharp relief. For that end, coordinated work of different organisations that should be stimulated by knowledge on the current status and the value of the water system in every park is needed.

\section{Bibliography}

Астаховская, Светлана (2017): Пейзажный парк Гатчины на страницах Кушелевских альбомов // Пейзажный парк в Европе и России: между Просвещением и романтизмом, под редакцией Бориса Соколова, Москва, Кучково поле, 170-185.

Генеральный план реконструкции Москвы (1935): Генеральный план реконструкции Москвы Москва, Московский рабочий.

Горбатенко Сергей (2015): Архитектурные маршруты Петра Великого. Спб., Историческая иллюстрация, С, 156.

Иванова, Елена (2017): Парк Безбородко в Москве - проект Николая Львова // Пейзажный парк в Европе и России: между Просвещением и романтизмом, под редакцией Бориса Соколова, Москва, Кучково поле, 198-215.

Косенко, Їван; Храбан, Георгий; Мітін, Виктор; Гарбуз, Владимир (1996): Дендрологічный парк Софіівка. Киів, Мистецьство, 35-90.

Ламеко, Ольга (2017): История Павловского парка в архитектурной графике и планах 18-19 веков // Пейзажный парк в Европе и России: между Просвещением и романтизмом, под редакцией Бориса Соколова, Москва, Кучково поле, 136-153.

Пащинская, Ирина (2017): Николай I - создатель романтических парков Петергофа // Пейзажный парк в Европе и России: между Просвещением и романтизмом, под редакцией Бориса Соколова, Москва, Кучково поле, 260-273.

Соколов, Борис (2018): Наследие Андре Ленотра и французское путешествие Петра I // Европейские маршруты Петра Великого, Санкт-Петербург, Европейский дом, 223-231.

Степаненко, Ирина (2017): Садовая империя Царского Села // Пейзажный парк в Европе и России: между Просвещением и романтизмом, под редакцией Бориса Соколова, Москва, Кучково поле, $114-121$. 
